\title{
НА ШЛЯХУ ПРОФЕСІЙНОГО ЗРОСТАННЯ ЛІКАРІВ-СТОМАТОЛОГІВ-ІНТЕРНІВ: ТЕНДЕНЦІЯ, ВИКЛИКИ ТА ПЕРСПЕКТИВА НА МАЙБУТНЄ
}

\section{Ivano-Frankivsk National Medical University \\ ON THE WAY OF DENTISTS-INTERNS PROFESSIONAL DEVELOPMENT: TRENDS, CHALLENGES AND PERSPECTIVES FOR THE FUTURE}

\begin{abstract}
Мета роботи - встановити у лікарів-стоматологів, які щойно стали спеціалістами, рівень працевлаштованості, сформованості знань про майбутні місце та режим роботи, рівень практичної підготовки на кафедрі стоматології післядипломної освіти та види безперервної стоматологічної освіти.

Основна частина. За результатами педагогічного моніторингу (анонімне анкетування) 141 лікаря-інтерна, який у 2017 р. закінчив навчання в інтернатурі на базі ННІПО ІФНМУ, встановлено, що переважна більшість має бажання працювати за своєю професією - 88,65 \% осіб. Від 90,07 до 93,62 \% лікарів володіють знаннями щодо облаштування робочого місця, обов’язків та організації робочого дня лікаря-стоматолога. Відмітили низький рівень працевлаштування лікарів-інтернів на момент закінчення навчання в інтернатурі - 59,57 \% не мали місця роботи та продовжували шукати. Навчаючись на очному циклі інтернатури, 87,94 \% осіб самостійно та з допомогою викладача здійснювали клінічний прийом пацієнтів. Лікарі-стоматологи-інтерни усвідомлюють, що навчання для професіоналів у галузі стоматології не може зупинитися після закінчення програми інтернатури.

Висновок. Проведене нами анкетування лікарів-стоматологів, які щойно закінчили навчання в інтернатурі, дозволяє сформувати уявлення про деякі аспекти функціонування стоматологічної післядипломної освіти на сьогоднішньому етапі та допоможе виділити ті ланки, які необхідно реформувати: працевлаштування, ефективні доступні форми післядипломного безперервного навчання.
\end{abstract}

Ключові слова: лікарі-стоматологи-інтерни; післядипломне навчання; працевлаштування; робоче місце; очний цикл навчання; безперервне навчання.

The aim of the work - to establish in dentists, who have just become specialists, the level of employment, knowledge formation about the future place and mode of work, the level of practical training at the Department of Dentistry of postgraduate education and the types of continuous dental education.

The main body. According to the results of pedagogical monitoring (anonymous questionnaire) 141 intern doctors, who graduated from internship in 2017 on the basis of Educational Scientific Institute of Post-graduate Education Ivano-Frankivsk National Medical University, we've found that the overwhelming majority had a desire to work in their profession - 88.65 \%. From $90.07 \%$ to $93.62 \%$ of doctors are knowledgeable about the arrangement of workplace, duties and organization of dentist workday.

A low level of employment of intern doctors at the time of graduation was noted - $59.57 \%$ did not have a place to work and continued to seek. Studying at full-time internship cycle, $87.94 \%$ on their own and with the help of teacher, conducted patient's clinical admission. Dental practitioners are aware, that training for professionals in dentistry can't stop after the end of internship program.

Conclusion. Our survey of dentists who have just graduated the internship, allows us forming an idea about some aspects of dental postgraduate education functioning at its current stage, and will help to identify the parts in need to be reformed: employment, effective accessible forms of postgraduate continuing education.

Key words: dentistry interns; postgraduate education; employment; work place; full-time study cycle; continuous education.

Вступ. Події в сучасній стоматологічній післядипломній освіті України певною мірою відображають соціальні закономірності суспільства. Тому неодноразово в різних джерелах зустрічаємо відо-

(c) Т. М. Дмитришин мості про шляхи реформування, які пов'язані із подовженням часу навчання на програмах спеціалізації, зменшенням потреби у вузькоспеціалізованих лікарях [1]. Також наводиться інформація про відміну атестацій кожні п’ять років, нарахування 
кредитних балів та їхній електронний облік, навчання як у державних, так і приватних установах у рамках безперервної стоматологічної освіти [2].

Та жодна $з$ реформ не заперечує, що сучасний лікар-стоматолог має володіти науковими і технологічними досягненнями, новими методами діагностики, лікування та профілактики основних стоматологічних захворювань [3].

Не чекаючи реформування, кафедри післядипломної освіти сприяють поширенню новітньої інформації лікарям-стоматологам: сучасних методів діагностики, лікування та профілактики основних стоматологічних захворювань, що дозволить підняти якість надання стоматологічної допомоги при проведенні підготовки, планування та виготовлення конструкцій зубних протезів із використанням актуальних методик [4].

Система післядипломної освіти формує основу безперервного професійного розвитку спеціаліста професійну компетентність. Це і мотивація до вибору професії, якості лікаря, професійні цінності, введення в курс інтернатури предмета психології, створення власних клінік [5].

Сучасне забезпечення якісної освіти лікарів-стоматологів грунтується на безперервному вдосконаленні, креативних ідеях, реалізованих на надійній матеріально-технічній базі. Перехід до нових комп’ютерно-орієнтованих технологій навчання, створення умов для їх розробки, апробації та впровадження, раціональне поєднання з традиційними вимогами часу - це складне педагогічне завдання, яке потребує розв'язання цілого комплексу психолого-педагогічних, організаційних, навчальнометодичних, технічних та інших проблем [6].

Таким чином, з одного боку, спеціалісти в системі післядипломної освіти не покладаючи рук працюють над вдосконаленням форм теоретичної та практичної підготовки лікарів-стоматологів-інтернів, а 3 іншого - у світлі активного реформування медичної освіти не належним чином вивчено точку зору молодих спеціалістів, які щойно закінчили навчання в інтернатурі і стали на шлях професійного розвитку.

Аналізуючи літературні джерела, ми не відмітили ретельного аналізу таких важливих питань післядипломної освіти, як рівень та критерії працевлаштування, готовність лікарів-інтернів самостійно проводити стоматологічний прийом, перевагу форм безперервного навчання, зокрема, і з врахуванням точки зору лікарів-стоматологів-інтернів.

Мета роботи - встановити у лікарів-стоматологів, які щойно стали спеціалістами, рівень праце- влаштованості, сформованості знань про майбутні місце та режим роботи, рівень підготовки на кафедрі післядипломної освіти та види безперервної стоматологічної освіти.

Основна частина. Для вирішення сформованої нами мети було застосовано метод педагогічного моніторингу - анонімне дослідження - анкетування. В анкетуванні взяв участь 141 лікар-інтерн другого року навчання, що 2017 р. закінчив навчання в інтернатурі на базі ННІПО ІФНМУ. Під час дослідження намагалися з'ясувати запитання щодо результатів ліцензійних іспитів “Крок 2”, “Крок 3”, ймовірності працювати за професією, наявності місця роботи, уявлення про майбутню професію за такими критеріями, як: місце роботи, що входить в обов'язки, організація робочого дня (графік роботи, звітність, ступінь навантаження). Декілька запитань стосувалися навчання на кафедрі післядипломної освіти. Зокрема, чи проводили стоматологічне лікування пацієнтів лікарі-інтерни на очному циклі інтернатури та як: особисто, з допомогою викладача, одногрупників, не приймали. Також цікаво було дізнатися, чи відповідали їхні очікування від навчання на очному циклі інтернатури реальному освітньому процесу.

Для ознайомлення $з$ рівнем знань щодо безперервної післядипломної освіти нами було сформовано запитання у вигляді таблиці. Як саме, на вашу думку, необхідно підвищувати свій рівень професійної майстерності: самоосвіта 3 книжок, журналів, інтернет-джерел; курси ПАЦ, ТУ на базі закладів післядипломної освіти; майстер-класи та лекції приватних лекторів, стажування, курси за кордоном? А також респонденти вказували частоту відвідування таких заходів: постійно, раз на 5 років, раз на 7 років, інша відповідь, ніколи.

За результатами проведеного нами анкетування лікарів-стоматологів-інтернів було встановлено, що середнє значення результатів ліцензійного іспиту “Крок 2” було 80,11 \%, а іспиту “Крок 3”- 83,69 \%, що свідчить про послідовність та якість підготовки спеціалістів. Слід зазначити, що іспит “Крок 3” із показником понад 80 \% склали 72,34 \% опитаних (102 особи), а з понад $90 \%$ - 13,48 \% (19 осіб).

Під час дослідження було встановлено високий рівень бажання лікарів-інтернів працювати за обраною професією - 88,65 \% (рис. 1). До осіб, які, на нашу думку, не будуть працювати за спеціальністю, а це 11,35 \%, віднесли 2,84 \%, які ще не визначилися, 2,84 \%, які поки що не працюватимуть за спеціальністю, та 5,67 \%, яким було складно відповісти на це запитання. 


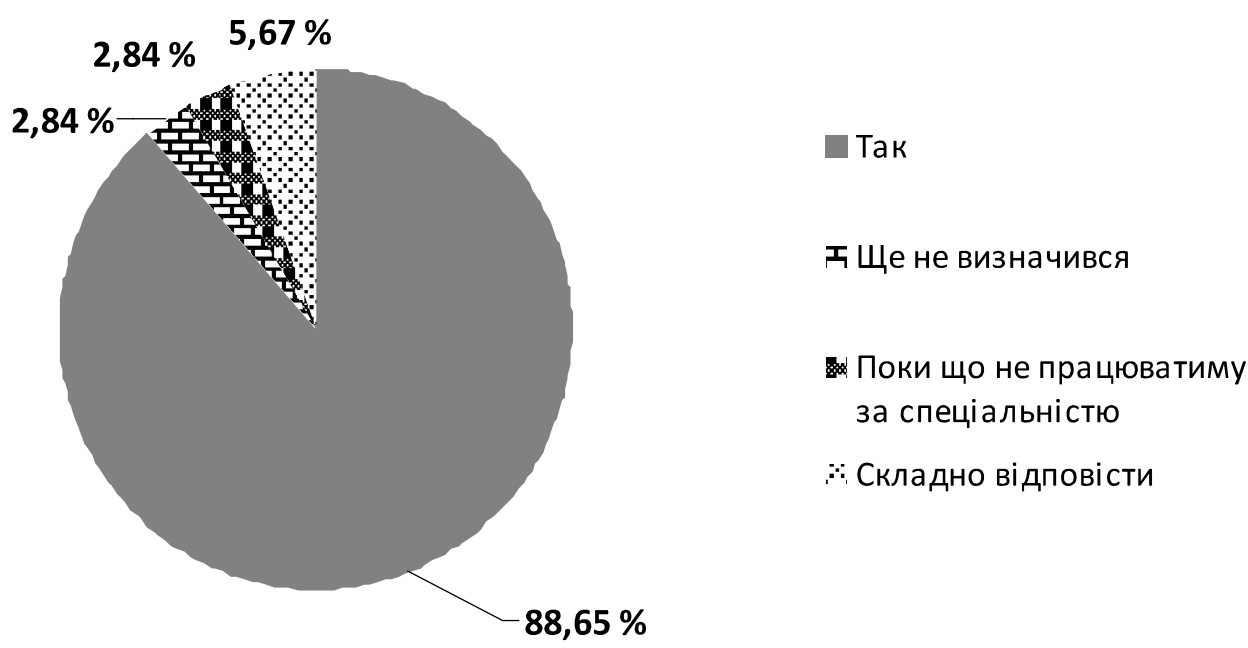

Рис. 1. Розподіл осіб (\%) за бажанням працювати за фахом.

Важливими для нас були відповіді на запитання, що стосувалися наявності місця роботи (рис. 2). Лише 37,59 \% лікарів-інтернів відповіли “так”,
32,62 \% зазначили, що ще шукають, а 26,95 \% вказали, що не мають. Незначний відсоток - 2,84 \% повідомили про продовження навчання.

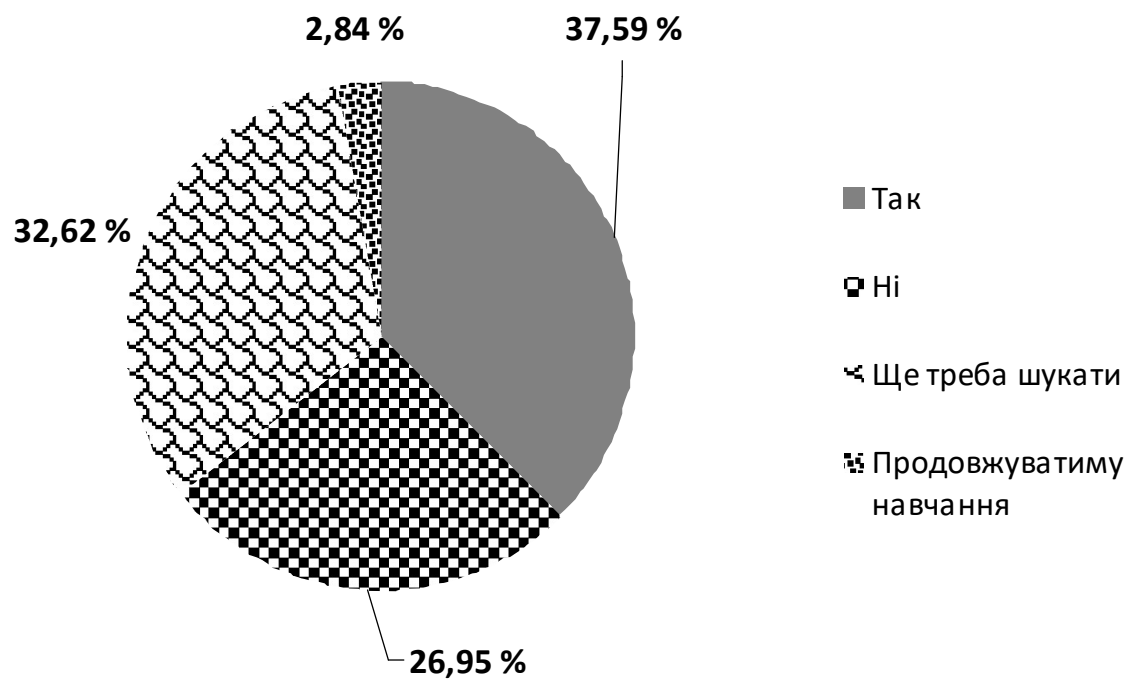

Рис. 2. Розподіл осіб (\%) за наявністю місця роботи.

Із 19 осіб, які написали ліцензійний іспит “Крок 3” на $90 \%$ і більше відсотків, 47,37\% лікарів-інтернів або не мали місця роботи, абоще шукали, 42,11 \% малимісце роботи, а 10,53 \% планували продовжити навчання. Це може вказувати на те, що високі результати ліцензійного інтегрованого іспиту не завжди є критерієм при працевлаштуванні молодих спеціалістів.

Відповідаючи на запитання щодо характеристики місця роботи (рис. 3), слід відмітити, що 44,68\% та 45,39 \% чітко та приблизно уявляли організацію робочого місця, натомість 4,26 \% зовсім не уявляли. Переважна кількість випускників - 71,63 \% чітко знають, що входить у їхні обов’язки. Щодо органі- зації робочого дня (графік роботи, звітність, ступінь навантаження) - 54,61 \% опитаних чітко уявляють, 36,88 \% - приблизно.

Намагаючись оцінити рівень оволодіння практичними навиками лікарів-інтернів, цікавилися, чи вони особисто вели клінічний прийом пацієнтів на очному циклі навчання (рис. 4). Так, 46,10 \% працювали самостійно, 36,88 \% - за допомогою викладача, 4,96 \% - як самостійно, так і з допомогою викладача. Таким чином, 87,94 \% опитаних вказали, що проводили практичний прийом. Лише 2,84 \% зазначили, що не приймали пацієнтів, а 4,26 \% не відповіли на це запитання. 


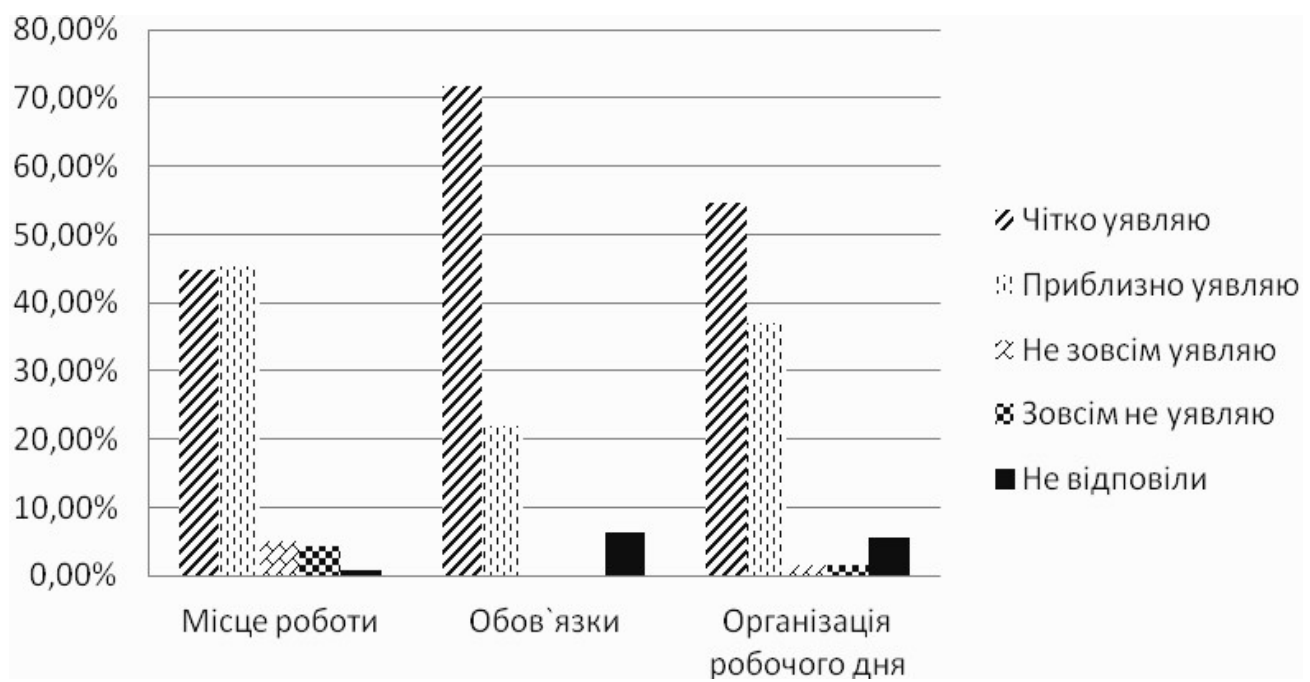

Рис. 3. Розподіл осіб за деякими критеріями професійної діяльності.

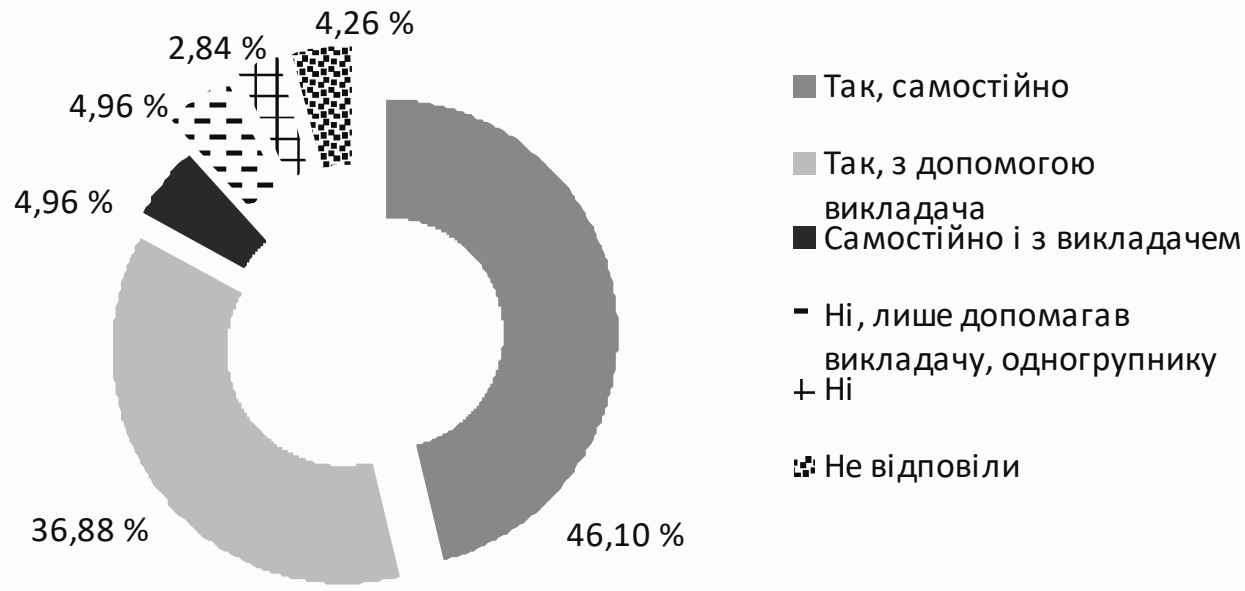

Рис. 4. Розподіл осіб (\%) щодо проведення клінічного прийому пацієнтів на очному циклі інтернатури.

Незважаючи на незначний досвід у функціонуванні системи післядипломної освіти, проте, зважаючи на те, що саме лікарі-інтерни є споживачами освітніх послуг, їм було запропоновано відповісти на запитання щодо відповідності очікування від навчання на очному циклі інтернатури реальному стану навчання (рис. 5). “Так, цілком” - відповіли 26,95 \% опитаних, “так, певною мірою” - 38,30 \%, “швидше, що ні” - 24,11 \%, “складно відповісти” зазначили 6,67 \% та не бажали відповісти на це запитання 4,96 \% респондентів. Враховуючи відповіді “так, цілком” та “так, певною мірою”, позитивну оцінку діяльності кафедри дали 65,25 \% лікарів-інтернів, незважаючи на те, що ці відповіді мали дещо суб'єктивний характер.

Значна кількість запитань присвячена баченню молодими спеціалістами майбутньої безперервної стоматологічної освіти (рис. 6).
Найбільше лікарів-стоматологів-інтернів відповіли, що хотіли би підвищувати рівень професійної майстерності, відвідуючи майстер-класи, лекції приватних лекторів - 95,74 \% та займаючись самоосвітою з книжок, журналів, інтернет-джерел 93,62 \%. Перевагу курсам підвищення кваліфікації (передатестаційні цикли, тематичне вдосконалення) віддали 84,4 \% опитаних. Також 82,98 \% осіб вказали на бажання проходити стажування чи інші види курсів за кордоном. Слід відмітити, що 12,06 \% респондентів мали іншу точку зору, а 4,96 \% - не відповіли на запитання щодо безперервної стоматологічної освіти. Результати переконливо засвідчують, що лікарі-стоматологи-інтерни вже ознайомлені із різноманітністю заходів, які дозволять їм підвищити професійну майстерність.

Молоді спеціалісти в більшості - 78,03 \% усвідомлюють, що для вдосконалення їхньої діяль- 


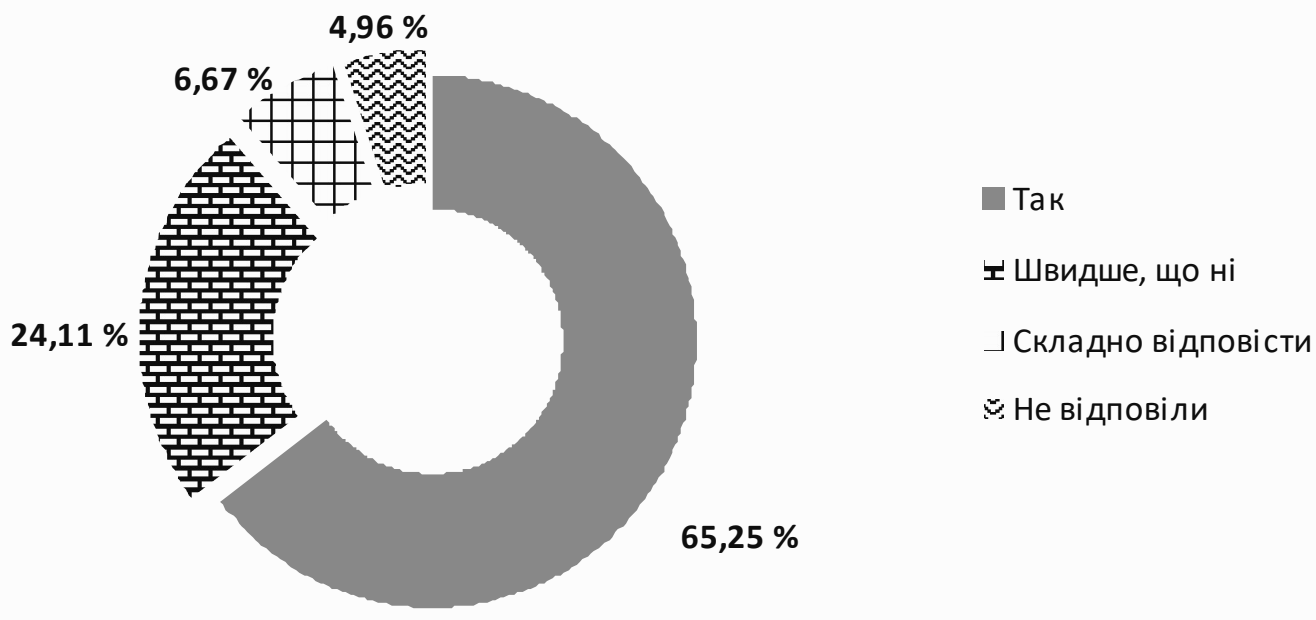

Рис. 5. Розподіл осіб (\%) за результатами щодо оцінки навчання на очному циклі інтернатури.

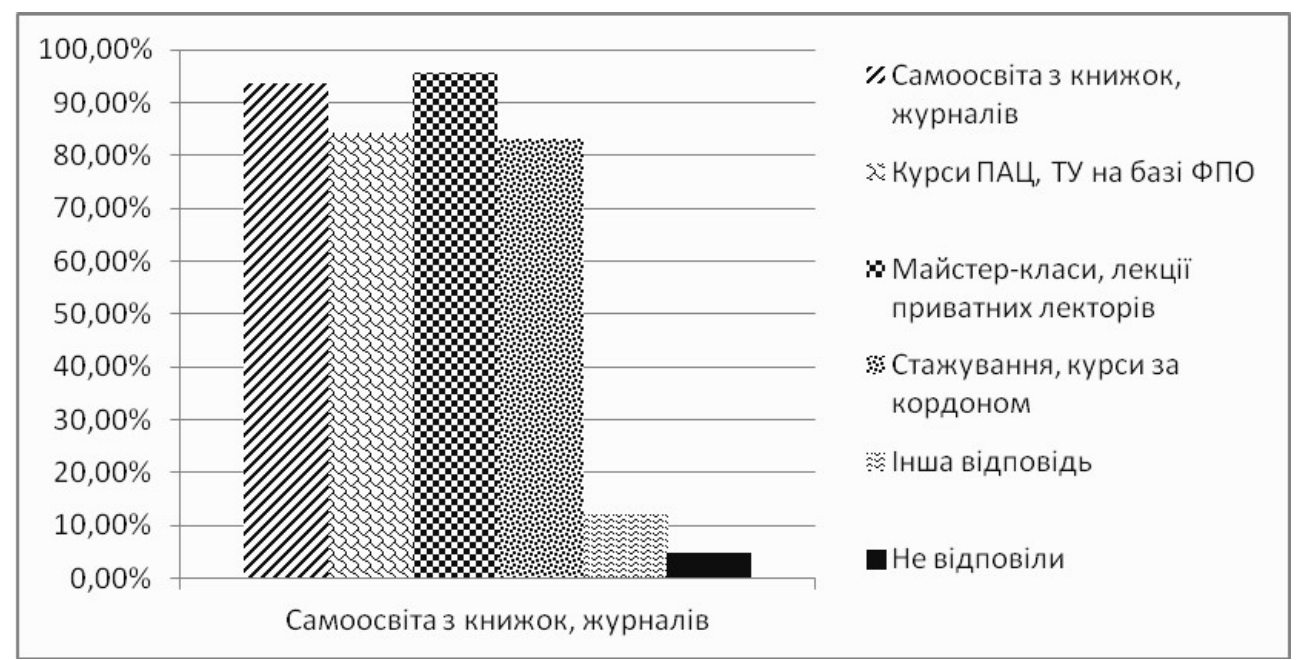

Рис. 6. Розподіл лікарів-стоматологів-інтернів щодо видів безперервної стоматологічної освіти.

ності необхідно постійно займатися самоосвітою, використовуючи інформацію з книжок, журналів, інтернет-ресурсів; 8,33 \% вважають, що достатньо “раз на п’ять років”, а 9,85 \% відповіли - “інколи, дуже рідко”; 1,52 \% не бачать необхідності в такого виду заходах підвищення своєї кваліфікації (рис. 7).

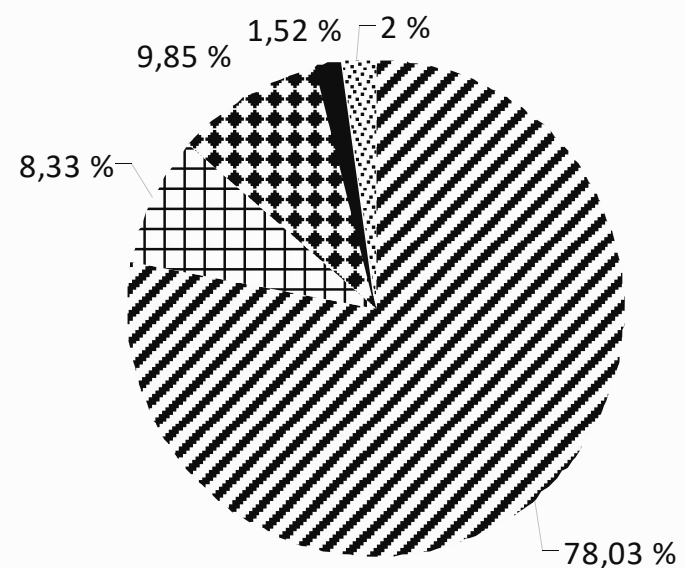

„ Так, постійно
+ Так, раз на 5 років

І Так, інколи, дуже рідко

$\mathrm{Hi}$

: Інша відповідь

Рис. 7. Розподіл осіб за частотою проведення заходів: самоосвіта з книжок, журналів, інтернет-джерел. 
По відношенню до частоти проведення курсів передатестаційних циклів та тематичного вдосконалення думки респондентів розділилися таким чином: “раз на п’ять років” відмітили 44,54 \%, “постійно” - 33,61 \%, “інколи, дуже рідко” - 10,93 \%, “не відвідувати” - 9,24 \% (рис. 8).
Великі надії покладають лікарі-інтерни в системі безперервної стоматологічної освіти на майстеркласи, лекції приватних лекторів. Зокрема, 66,67 \% вважають, що їх треба відвідувати “постійно”, 14,22 \% - “раз на п’ять років”, 13,3 \% - “інколи, дуже рідко”, 2,96 \% - “не відвідувати”, а 2,22 \% запропонували іншу відповідь (рис. 9).

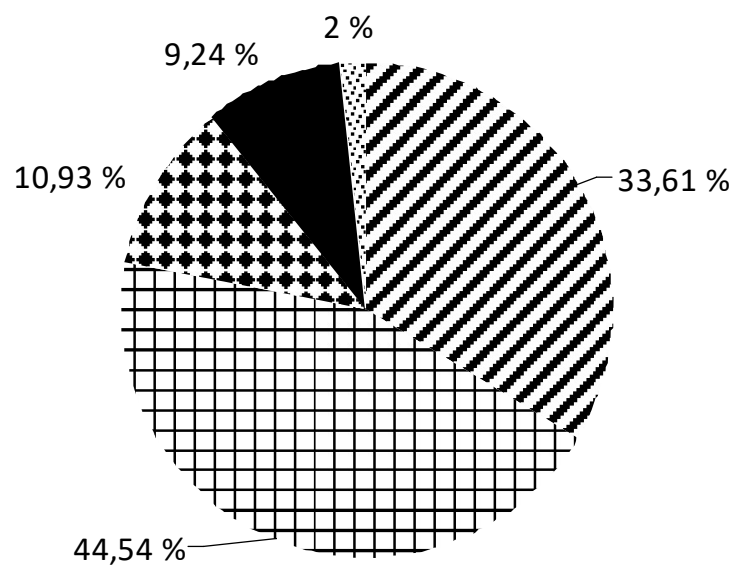

- Так, постійно

- Так, раз на 5 років

. Так, інколи, дуже рідко

口 $\mathrm{Hi}$

Ћ Інша відповідь

Рис. 8. Розподіл осіб за частотою проведення заходів: курси ПАЦ та ТУ на базі державних закладів післядипломної освіти.

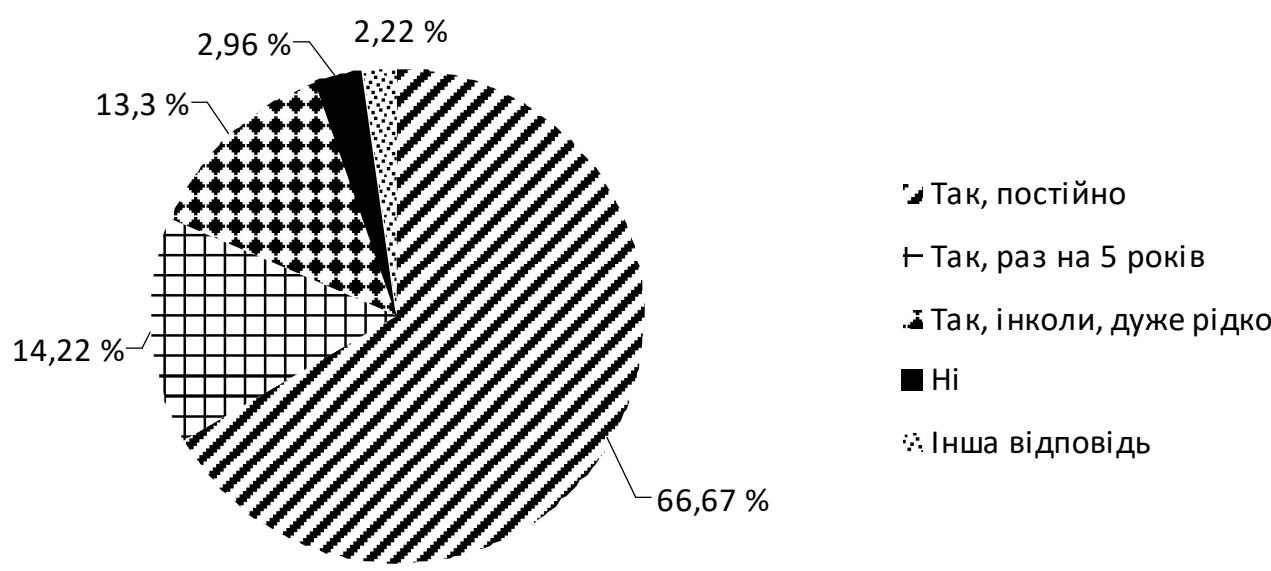

Рис. 9. Розподіл осіб за частотою проведення заходів: майстер-класи, лекції приватних лекторів.

На нашу думку, неабиякий вплив на формування відповіді щодо видів безперервної стоматологічної освіти має реклама приватних курсів та лекцій, натомість, напевно, жодна $з$ державних установ післядипломної освіти не використовує у своїй діяльності таку маркетингову послугу.

Половина опитаних - 51,28 \% зазначили, що для підвищення професійної майстерності необхідно постійно проходити стажування чи інші види курсів за кордоном (рис. 10). “Інколи, дуже рідко” збираються відвідувати такі курси 20,51 \% лікарівінтернів, по 12,82 \% вважають, що достатньо буде “раз на п’ять років” чи “не відвідувати”.
Наведені результати відповідей щодо безперервної стоматологічної освіти на шляху підвищення рівня професійної майстерності мають рекомендаційний характер, оскільки респонденти ще не мали досвіду роботи. Виходячи з цього, їм було складно сформувати свою аргументовану думку щодо вибору виду безперервної освіти, частки важливості кожного з них та частоти навчання. Про це свідчать відсотки осіб, які вказували на “інша відповідь" 12,06 \% (17 лікарів-інтернів), проте не змогли чітко сформулювати свою думку, а також 4,96 \% (7 лікарів-інтернів), які не відповідали на запитання стосовно безперервної післядипломної освіти. 


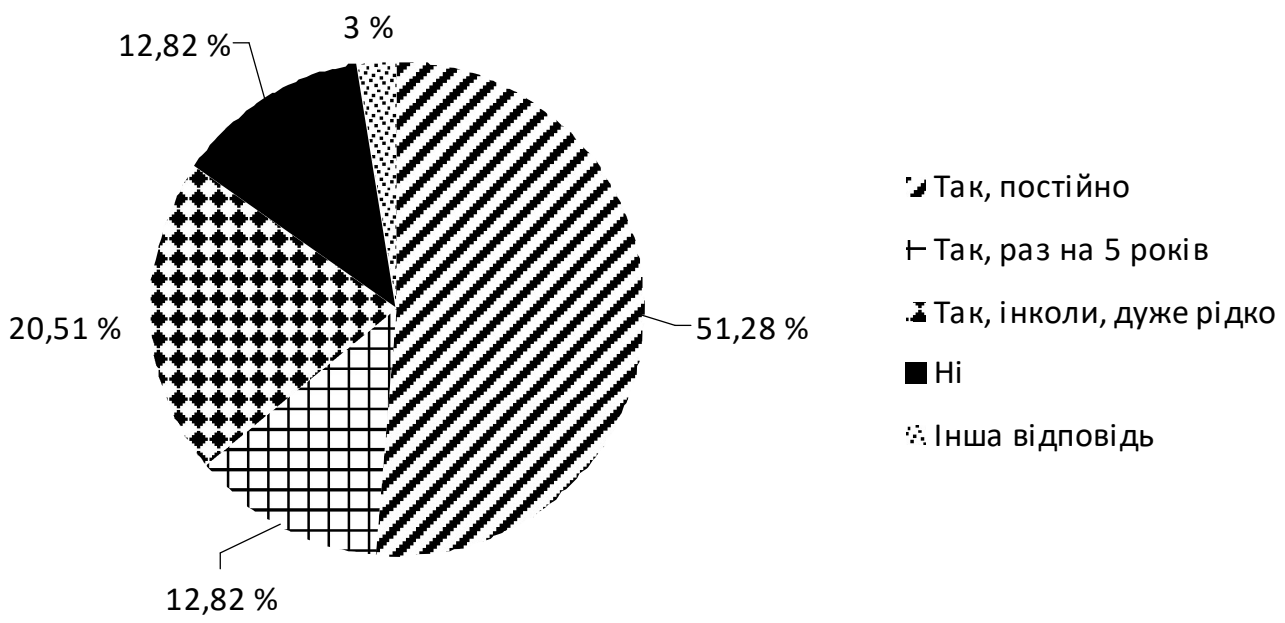

Рис. 10. Розподіл осіб за частотою проведення заходів: стажування та інші курси за кордоном.

Підсумовуючи, хочемо зазначити, що проведене нами анкетування лікарів-стоматологів-інтернів дозволяє сформувати уявлення про деякі аспекти функціонування стоматологічної післядипломної освіти на сьогоднішньому етапі та допоможе виділити ті ланки, які необхідно реформувати.

Висновки. 1. Лікарі-стоматологи відразу після закінчення навчання в інтернатурі у переважній більшості мають бажання працювати за своєю професією, це 88,65 \% осіб. Більшість із них, тією чи іншою мірою, володіють знаннями щодо робочого місця, обов'язків та організації робочого дня лікаря-стоматолога (90,07-93,62 \%).

2. Проведене нами анкетування підтвердило таку важливу проблему, як низький рівень працевлаштування лікарів-інтернів на момент закінчення навчання в інтернатурі (59,57 \% не мали місця роботи та продовжували шукати). Крім того, 47,37 \% респондентів, а це 9 осіб із 19, які мали високі ре-

\section{Список літератури}

1. Угрин М. Концепция реформы подготовки врачей-стоматологов Украины / М. Угрин, М. Солонько, О. Штука // ДентАрт. - 2015. - № 1. - С. 4-8.

2. Павленко О. В. Шляхи реформування системи надання стоматологічної допомоги населенню України. Дискусія / О. В. Павленко, О. М. Вахненко // Современная стоматология. - 2013. - № 4. - С. 180-184.

3. Косенко К. М. Особливості умов формування українського ринку стоматологічних послуг / К. М. Косенко, О. Е. Рейзвіх // Дентальные технологии. - 2012. № 3/4. - С. 6-13.

4. Омельяненко О. А. Сучасні аспекти підготовки лікарів стоматологів-ортопедів у системі післядипломної освіти / О. А. Омельяненко // Збірник наукових праць співробітників НМАПО ім. П. Л. Шупика. - К., 2015. Вып. 24 (1). - С. 645-649. зультати ліцензійного іспиту “Крок 3” - 90 \% і більше відсотків, також не були працевлаштованими.

3. Зі слів лікарів-стоматологів-інтернів, навчаючись на очному циклі інтернатури, 87,94 \% відмітили, що самостійно та з допомогою викладача здійснювали клінічний прийом пацієнтів. Також 65,25 \% осіб відмітили, що їхні очікування від навчання на очному циклі інтернатури цілком та певною мірою відповідали реальному освітньому процесу.

4. Лікарі-стоматологи-інтерни усвідомлюють, що навчання для професіоналів у галузі стоматології не може зупинитися після закінчення програми інтернатури та у переважній більшості вважають, що для цього $є$ необхідними самоосвіта $з$ літературних джерел, відвідування приватних освітніх програм як в Україні, так і за кордоном, а також навчання на передатестаційних циклах, курсах тематичного вдосконалення на базах закладів післядипломної освіти.

5. Соколова I. І. Особливості становлення професійної компетентності лікаря-стоматолога-інтерна / I. I. Соколова, О. Г. Денисова, О. Ю. Стоян // Сучасний стан та перспективи підготовки лікарів-інтернів у ХНМУ : матеріали 42-ї наук.-метод. конф. $з$ інтернатури, Харків, 26 квітня 2016 р. - Х., 2016. - С. 96-98.

6. Сучасні підходи до забезпечення якісної освіти лікарів-стоматологів / В. М. Ждан, В. М. Бобирьов, О. В. Шешукова [та ін.] // Кредитно-модульна система організації навчального процесу у вищих медичних (фармацевтичному) навчальних закладах України на новому етапі : матеріали $\mathrm{X}$ ювілейної Всеукр. навч.-наук. конф. $з$ міжнар. участю, Тернопіль, 18-19 квітня 2013 р. // Медична освіта. - 2013. - № 2.- С. 65-68. 


\section{References}

1. Ugrin, M., Solonko, M., \& Shtuka, O. (2015). Kontseptsiya reformy podgotovki vrachey-stomatologov Ukrainy [The concept of Ukrainian dentists training reform]. DentArt, 1, 4-8 [in Russian].

2. Pavlenko, O.V., \& Vakhnenko, O.M. (2013). Shliakhy reformuvannia systemy nadannia stomatolohichnoi dopomohy naselenniu Ukrainy. Dyskusiia [Ways of reforming the system of providing dental care to the Ukrainian population. Discussion.]. Sovremennaya stomatologiya - Modern Dentistry, (4), 180-184 [in Ukrainian].

3. Kosenko, K.M., \& Reizvikh, O.E. (2012). Osoblyvosti umov formuvannia ukrainskoho rynku stomatolohichnykh posluh [Features of the condition formation of Ukrainian dental services market]. Dentalnye tekhnologii - Dental Technologies, 3/4, 6-13 [in Ukrainian].

4. Omelianenko, O.A. (Ed.). (2015). Suchasni aspekty pidhotovky likariv stomatolohiv-ortopediv u systemi pisliadyplomnoi osvity [Modern aspects of prosthetic detists training, in the system of postgraduate education]. Zbirnyk naukovykh prats spivrobitnykiv NMAPO im. P.L. ShupykaCollection of scientific works of staff member of P.L. Shupyk NMAPE. Kyiv: Natsionalna medychna akademiia pisliadyplomnoi osvity imeni P. L. Shupyka, 24 (1), 645649 [in Ukrainian].

Електронна адреса для листування: ddm1972@ukr.net
5. Sokolova, I.I., Denysova, O.H., \& Stoian, O.Iu. (Eds.) (2016). Osoblyvosti stanovlennia profesiinoi kompetentnosti likaria-stomatoloha-interna [Features of professional competence becoming of a dentist-intern]. Suchasnyi stan ta perspektyvy pidhotovky likariv-interniv u KhNMU: materialy 42-i nauk.-metod. konf. z internatury - Current State and Prospects of Interns training in KhNMU: materials of the 42-th Sci.-Method. Conf. On Internship. Kharkiv: Kharkiv National Medical University, 96-98 [in Ukrainian].

6. Zhdan, V.M., Bobyrov, V.M., Sheshukova, O.V., Lokhmatova, N.M., \& Sharbenko, T.V (Eds.). (2013). Suchasni pidkhody do zabezpechennia yakisnoi osvity likariv-stomatolohiv [Modern approaches to quality ensuring of dentist's education]. Kredytno-modulna systema orhanizatsii navchalnoho protsesu u vyshchykh medychnykh (farmatsevtychnomu) navchalnykh zakladakh Ukrainy na novomu etapi: mater. X yuvileinoi Vseukr. navch.nauk. konf. z mizhnarodnoiu uchastiu - Credit-transfer educational process system organization in higher medical (pharmaceutical) educational institutions of Ukraine at a new stage: mater. X Anniversary All-Ukr. Educational Sciences. Conf. with International Participation, Ternopil: Medychna osvita - Medical Education, 2, 65-68 [in Ukrainian].

Отримано 03.11.17 